\title{
THE CHRONIC RHEUMATIC DISEASES IN THE WORLD WAR 1939-1945
}

\author{
BY
}

\section{W. S. C. COPEMAN}

The chronic rheumatic diseases have played an undramatic role in the medical history of this war. Consequently, comparatively little reference to them is to be found in the available reports of the consultants in medicine in the various theatres of war. There can be no doubt, however, that their " nuisance value" was in the aggregate considerable and at times produced a mild man-power problem in certain regions, whilst the hospital bed situation was also adversely affected owing to the length of the average stay of rheumatic patients in hospital. For information concerning this aspect it is necessary to consult the quarterly reports of the officers in charge of medical divisions of general hospitals; and for the purpose of this account samples of these have been taken and will be referred to below.

\section{Types of Disease}

The types of disease at issue are, as would be expected in a selected body of young men, chiefly those of the non-articular group. These are to be found variously classified under such headings as fibrositis, fibromyositis, myalgia, "rheumatism," and even "pain of psychosomatic origin." In addition there are the well-recognized anatomical classifications under such headings as lumbago, sciatica, pleurodynia, torticollis, brachial neuritis, etc.

\section{Incidence}

Interest in these conditions is not universal amongst medical men, with the result that information on which to base an accurate estimate of their rate of incidence is widely scattered. Those reports which have been found to be most helpful are reproduced below. The difficulties inherent in the lack of a standardized nomenclature have already been referred to, whilst finally it must be noted that a number of cases were admitted to surgical divisions and retained there, more especially if orthopaedic facilities were available. The number of these cases is known to have been considerable, but is not included in the figures given below. All these factors make it difficult to give an exact picture of the incidence of this disease-group during the late war-although an estimate may be arrived at from a study of the samples given below for the various theatres of operation, since they are believed to be generally representative.

\section{Age Groups}

In view of the fact that the Army personnel were a selected group within comparatively limited age limits, little information of value can be extracted with regard to the age-group liability to the various types of rheumatic disease. It becomes evident, however, that the non-articular forms are far from being the prerogative of the middle-aged and ancient, as is sometimes taught. Osteo-arthritis was generally the direct result of trauma, which accounts for its comparative frequency.

\section{Precipitating Causes}

The concensus of informed opinion is that the precipitating factors which have seemed principally operative in all theatres have been febrile illness, trauma, and exposure to severe climatic stress, of which cold appeared to be the major element.

Cold, damp, and changes in weather.-The majority of the men at risk were conditioned by long training to withstand a degree of exposure not normally encountered in civil life. Those who reasonably attributed their symptoms directly to exposure described such conditions as night patrols in the snow; sleeping on concrete floors or in slit trenches; lying in mud and wrapped only in a blanket; spending days at a time in wet clothes after crossing rivers; continual exposure to the fierce, damp draught which concentrates on the driver's seat in a Sherman tank; dispatch-riding in all weathers; or wading ashore from landing craft. The common factor in all these experiences is cold with insufficient protection to a degree approaching or exceeding the limit of individual tolerance, either alone or in conjunction with over-exertion, fatigue, or physical strain. Another significant factor appeared to be the variability of the conditions to which forward troops had to adjust themselves. Periods of relatively good living alternated with periods of full exposure to the weather. Sudden changes of weather bringing low temperatures, wind, rain, or snow exerted their full effect on soldiers living in the open without cover. The protection afforded by clothing is lost when the clothes become wet, and in these circumstances, even in relatively warm weather, a man is subjected to considerable cold stress. However well-conditioned a man may be, there are periods in such an existence when he is reduced to a state of shivering misery which is tempered only by his preoccupation with the job in hand.

An attempt to correlate recent physiological observations with the onset of rheumatism precipitated by such conditions was made (Copeman and Pugh, in 113 General Hospital, B.L.A., 1945), and the effect of such climatic conditions on intracellular 
tension was shown. It was demonstrated that these changes are reversible by means of dehydration. It seems possible that some therapeutic advance is foreshadowed by this work.

Trauma.-It is generally accepted that the increased mechanization of the Army resulted in a higher morbidity rate from both non-articular rheumatism and osteo-arthritis. This would have been expected from the data generally available from civilian industry prior to the war, and calls for no special comment.

Infection.-Focal infection met with little confirmation as an aetiological cause for the rheumatic syndromes observed in the Army. In a group of young men so carefully selected as were the forward fighting troops, it was a comparatively simple matter to exclude it.

The observation was made (Copeman, 1943) during an epidemic of influenza, that the pain in the back of which these patients complained was referred from trigger points similar in every way to those characteristic of fibrositis. It was observed, moreover, that although in a majority of patients these points disappear during their convalescence, in others they remain, unknown to the patient, until they are reactivated by any subsequent febrile illness or exposure. It seemed that in this way they may prove to be the basis for subsequent chronic fibrositis.

\section{Morbid Anatomy}

A considerable amount of work was carried out, largely at the Military Hospital for Head Injuries at Oxford, on the subject of sciatica caused by prolapsed intervertebral discs. It seems to be the general opinion of officers in charge of medical divisions that about $70 \%$ of cases seen in their hospitals could be correlated with this lesion, although neurologists are inclined to claim $90-95 \%$. It appears that very few soldiers affected in this way reverted to useful employment in the Army.* Elliot and Kremer also showed that a lesion of the cervical intervertebral discs could be demonstrated in certain cases of brachial neuritis. Elliot, noticing that certain fibrositic " nodules" disappeared as the result of treatment, produced myographic evidence to confirm his view that these lesions were, in fact, local collections of muscle fibres in spasm.

Working in Sicily (33 General Hospital) Copeman and Ackerman (1944) showed by biopsy that the "nodule" in the cases under our care consisted in a local non-inflammatory oedema of the fibro-fatty tissues in certain regions, which might result in herniation of affected fat lobules through their fibrous investment, where this was deficient. They showed that removal of these lobules would cure the pain complained of. These observations were confirmed by Mylechreest working in the same hospital. His findings are published in an M.D. thesis accepted by Cambridge University (1945).

Pugh and Christie (1945) examined 500 healthy.

* In response to a questionnaire circulated privately. soldiers in B.L.A. and found that non-tender nodules could be found in many-equally in rheumatic and in non-rheumatic subjects - but that tender nodules and trigger points were found in only $3 \%$ of men who did not give a clear history of fibrositis, as compared with $32 \%$ in those who did. Thus it seemed that non-tender nodules can be considered to be of no importance, whilst tender nodules must be correlated definitely with a rheumatic " diathesis."

British Expeditionary Force (to France)

In 1939, at the outset of war, a large number of reservists were recalled to the colours; a number of them being middle-aged men who were not extremely fit. As the result of the fairly primitive conditions in some regions at the outset, a fair number broke down. Dyspepsia seemed to be the principle evidence of this, although " rheumatism " accounted for $15 \%$ of all admissions into Nos. 2 and 3 General Hospitals during the first 4 months, and $26 \%$ of all medical admissions (Copeman, 1940). The Medical Society of Dieppe Medical Base area, under the Chairmanship of Major-General R. Priest, F.R.C.P., invited the writer in March, 1940, to discuss this matter. He showed that of the first 100 cases of " rheumatism " admitted to No. 3 General Hospital, rheumatic fever accounted for $15 \%$ (acute and subacute), chronic polyarticular rheumatism (? infective) for $6 \%$, osteoarthritis for $9 \%$, and fibrositis-mostly first attack attributed to exposure or trauma-for $70 \%$. He demonstrated a primitive but effective field treatment centre in which all the apparatus had been improvised from salvage material. (He was later awarded the gold key of the American Congress of Physiotherapy for this work.)

The experiment of grouping all rheumatic patients into special tents adjoining this centre was tried (Lt.-Col. F. Holmes, O.B.E.) and in spite of adverse factors such as leaking tents and the coldest winter for many years, the results of therapy at once improved. This was attributed to the active co-operation of the patients, which was obtained as the result of the increased interest and activity which this system produced in the nursing and medical staff concerned.

In June, 1940, Stott and Copeman published a paper describing 27 cases which had mostly been thought to be rheumatism. They were able to show conclusively that these were actually suffering with chronic meningococcal septicaemia, and further, that such cases, although comparatively rarely diagnosed as such, are in fact not uncommon.

The high admission rate for rheumatism was beginning to fall during the two months (April, May) which preceded the Army's evacuation of France in 1940.

\section{Middle East Force}

The consulting physician to this Force (Brigadier W. D. D. Small), discussing the subject of "rheumatism" in his report for the quarter ending Sept. 30, 1940, stated that rheumatism following rheumatic fever was "of a more chronic type than 
that seen in civilian practice at home. Small joints were more frequently affected, whilst cardiac complications were thought to be fewer, especially with first attacks. It did not respond to salicylates." In April, 1942, he held a conference in Cairo to which all officers in charge of divisions and many medical specialists were summoned. In opening this he stated that the subject of rheumatism in the Middle East needed discussion since the general conclusion which had been reached by his predecessors was that, whilst it was probable that the types of rheumatism seen in Egypt were essentially the same as those seen at home, it would seem probable that there were certain local variations in their clinical features or course. Rheumatism, in the wider sense, was, he said, the cause of a great deal of illness requiring admission to hospital, and in Egypt the acute forms did not respond well to salicylates.

Lt.-Col. I. W. G. Hill had formed the impression that rheumatism of all forms was commoner in Palestine than in Egypt, and that it accounted for a considerable wastage in manpower. The high incidence of these diseases was, he said, acknowledged by the civilian authorities in Jerusalem. Captain J. H. L. Easton emphasized the frequency of sciatica and fibrositis amongst Libyan prisoners of war.

Lt.-Col. J. C. Hawksley agreed that clinical types might be expected to vary in different localities, as did certain factors which might be expected to influence them. In the Suez area the incidence was low. Out of 12,500 admissions in the year ending March 31,1942 , only $1.33 \%$ were rheumatic. These cases averaged 25 days in hospital. He pointed out that, if the figures for cases treated at M.I. rooms and O.P. Department were included, it would be seen that " these minor cases form a big problem of their own." He pointed out that many were probably admitted to surgical divisions and were retained, more particularly those cases of sciatica in association with the typical fibrositic syndrome, which had occurred rather frequently amongst certain types of worker, especially railway-men and lorry drivers.

At this conference the syndrome was first reported which eventually became so well known in this theatre of operations: the triad of arthritis, conjunctivitis, and non-venereal urethritis-believed to be a late result of bacillary dysentery. It was stated that these cases generally healed, but that they might progress to chronic arthritis. One case, which had developed florid rheumatoid arthritic deformities, was described. Lipscomb and Sydney Smith stated that they had never previously seen this syndrome during long service in India.

Major M. Sarwar, I.M.S., reported that, although rheumatism of all forms was relatively uncommon in India, "it had been a great problem amongst Indian troops in Middle East during the last year."

Lt.-Col. C. C. McDonald commented on " the large problem of chronic rheumatism and fibrositis amongst Australian troops" which caused a serious wastage. He regarded an anxiety neurosis as a frequent aetiological factor, and it was in his view encouraged " by indulgent orthopaedists and physicians." Lt.-Col. E. Bulmer stated that, of 1,750 medical cases admitted during the previous quarter, 101 were for fibrositis. Many of these cases had developed the condition for the first time after lying in damp forward surroundings. $\mathrm{He}$ also found it excessively commonly complained of amongst Cypriot labour battalions.

Subsequent to this no further reference to the rheumatic diseases is to be found in the reports of the consulting physician. With a view to estimating the incidence of these diseases subsequently, the quarterly reports of the officers in charge of divisions have been perused and an abstract is appended from the two in which most information is to be found, i.e. No. 19 General Hospital and No. 2 General Hospital, when they moved to Tripoli in 1943.

The impression gained from reading the reports is that treatment in this disease group was seldom adequate, for the following reasons: the hurried examination and often inaccurate diagnosis given by the first medical officer to see the case-this was often an R.M.O. in a forward area; the lack of interest in these cases, as opposed to acute or rarer forms of disease; the frequent need to transfer cases from one hospital to another on account of the military situation; and, finally, in some cases, the absence of suitable physiotherapeutic apparatus. ${ }^{*}$

\section{Middle EAST}

No. 19 General Hospital, Tripoli (Lt.-Col. J. G. Scadding)

April-June, 1943.

Total medical admissions, 2,800 .

Arthritis: acute, 6.

Fibrositis, 29.
Sciatica, 8.

" subacute, 11.

Total prisoner-of-war admissions, 928; " rheumatic," 10.

Of 143 Medical Boards, 11 were on account of "rheumatism."

Of 120 out-patients seen, 13 were for " rheumatic" diseases.

July-September, 1943.

Total medical admissions, 2,600 .

Polyarthritis: acute, 11.

Arthritis, mo subacute, 20.

Fibrositis (mostly lumbago), 21.

Sciatica, 7.

Spondylitis, ankylosing, 1 .

Of 99 Medical Boards, 8 were on account of "rheumatic" diseases.

Of 59 out-patients seen, 4 were for "rheumatic" diseases.

October-December, 1943.

Total medical admissions, 2,839 .

Polyarthritis: acute, 11 .

, subacute, 2.

Arthritis, monarticular, 5.

Fibrositis (lumbago), 33

Sciatica, 5.

In addition, 6 prisoners-of-war were admitted with "rheumatism."

Of 142 Medical Boards, 6 were on account of "rheumatic" diseases.

Of 68 out-patients seen, 5 were "rheumatic" diseases.

* Also a questionnaire circulated privately to officers in charge of divisions. 
January-March, 1944.

Total medical admissions, 1,900.

Polyarthritis: acute, 14.

Arthritis, monacute, 7.

Fibrositis and lumbago, 39

Sciatica, 8.

Synovitis, acute, 3 .

Spondylitis, ankylosing, 1.

April-June, 1944.

Total medical admissions, 1,588.

Polyarthritis: acute, 16. subacute, 5 .

Arthritis: monarticular, 6. gonococcal 1.

Fibrositis (and lumbago), 29.

Sciatica, 3.

Synovitis, 1.

In addition, acute rheumatism was seen in two West

African native soldiers, and fibrositis in one.

July-September, 1944.

Total medical admissions, 3,770.

Acute rheumatism, 8 .

Subacute rheumatism, 10.

Fibrositis, lumbago, etc., 22.

Osteo-arthritis, 5.

Sciatica, 4.

Spondylitis, 2.

Case history: West African soldier, aet. 25. (Pyomyositis tropica.) Onset of general muscular pains one month previously. Gradual appearance of small, ill-defined, slightly tender, firm lumps in right triceps and quadriceps muscles. General condition, good. Further nodules had recently appeared in right latissimus dorsi and left quadricepts. He was admitted to hospital. On examination he had mild fever. Pulse was 72 . White cells, 11,000 per 100 c.mm. of blood. (Polymorphs $72 \%$.) Kahn \pm . All other examinations were negative. The nodules in latissimus dorsi were punctured, and a little sanguino-purulent material was obtained. Haemolytic Staph. aureus was grown on culture. The patient made an uneventful recovery after 75 g. sulphapyridine, and nodules disappeared.

October-December, 1944.

Total medical admissions, 2,700.

Acute rheumatism, 15.

Subacute rheumatism, 6 .

Fibrositis, 21.

Osteo-arthritis, 6.

Rheumatoid arthritis, 3.

Sciatica, 13.

Synovitis, 1

As can be seen, the group was not a very large problem on account of size, but has made up for this on account of refractoriness to treatment. One group of cases might be noted. This was one of 33 cases of polyarthritis occurring between July and October, 1943. All these men came from the desert and had been living in tents. Usually knees, ankles, wrists, and elbows were affected, but not infrequently the small joints of the hands were attacked as well. Pain was a more noticeable factor than swelling. The cyclical involvement of acute rheumatism was not noticeable, but the arthritis, nearly always multiple, persisted for some time and responded poorly to salicylates. Pyrexia tended to be slight but persistent, and tachycardia was moderate. No case of carditis was seen, and there was no enlargement of lymph nodes. Search for focal sepsis was unproductive. A past history of acute rheumatism was rarely obtained, but previous joint pains had been fairly frequent. Those affected were rarely discharged from hospital in less than 6 weeks. The erythrocyte sedimentation rate was considered to be the most useful guide to progress.

\section{No. 2 General Hospital, Tripoli} (Lt.-Col. H. R. Donald)

April-June, 1943.

Total medical admissions, 4,300.

Rheumatic diseases, subacute and chronic, excluding neuritis, 143.

Acute rheumatic fever, 8 .

July-September, 1943.

Total medical admissions, 5,000.

Rheumatic diseases, subacute and chronic, 98. Acute rheumatic fever, 10.

October 1st-25th, 1943.

Rheumatic diseases, subacute and chronic, 21. Acute rheumatic fever, 10.

An appendix to one of the reports of the advisor in physical medicine to the Middle East (Lt.-Col. G. Kersley) is worth quoting for the total figures included for the various countries comprised in this Command :

" Rheumatic Diseases in M.E., 1943-44.

"A review of all available statistics on ' rheumatic' cases from Military Hospitals in M.E. covering the period of 18 months has been carried out. In considering the findings, the following factors must be borne in mind: (a) the movement of troops and convoys of wounded from one locality to another; (b) inexactitude in terminology in many cases; (c) the Palestinian temperament; (d) climatic conditions.

"Among the cases of acute rheumatism are probably included many cases of acute non-traumatic synovitis of doubtful aetiology seen so frequently in the hot weather and which resemble rheumatic fever except for the absence of cardiac sequelae. Under arthritis, unless specifically noted, are included cases of rheumatoid, infective and osteo-arthritis, and also the syndrome of non-specific urethritis, conjunctivitis, and arthritis.

"Incidence of rheumatic diseases admitted to hospital, including fibrositis and sciatica, in comparison to the total medical admissions:

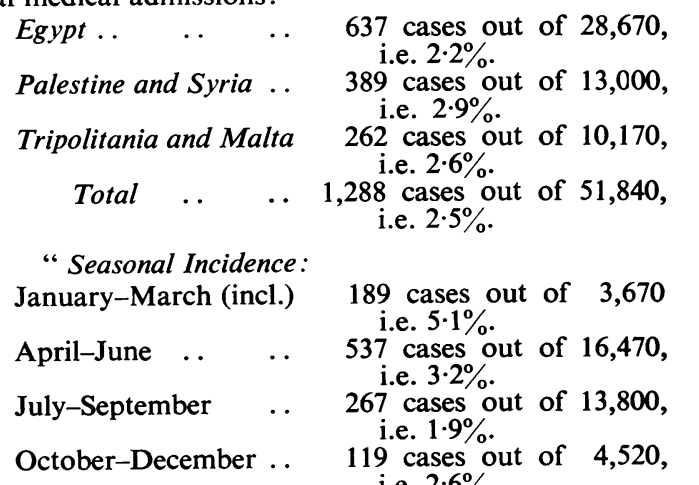
cases out of 28,670 ,
i.e. $2 \cdot 2 \%$. cases out of 13,000 , i.e. $2 \cdot 9 \%$

i.e. $2 \cdot 6 \%$. 
" Types of Rheumatic Diseases:

\begin{tabular}{lllll}
\multicolumn{2}{l}{ Acute rheumatism .. } & $\ldots$ & 250 \\
Arthritis &. &. & $\ldots$ & 164 \\
Fibrositis &. &. & $\ldots$ & 253 \\
Sciatica &. &. & $\ldots$ & 108
\end{tabular}

" Of 199 cases grouped as arthritis, $18 \%$ were classed as osteo-arthritis."

\section{Central Mediterranean Force}

No. 33 General Hospital, Sicily

(Lt.-Col. W. S. C. Copeman)

January-March, 1944.

Total medical admissions, 2,662.

Fibrositis (gluteal, 60; lumbar, 38), 105.

Subacromial bursitis, 1.

Sciatica, 13.

Polyarthritis: acute, 14.

Synovitis, 3.

infective, 2 .

Spondylitis, ankylosing, 3.

Osteo-arthritis, 3.

Rheumatoid arthritis, 2.

Arthritis, gonococcal, 3.

Extracts from Accompanying Report.- "At this period the 8th Army were crossing the Straits of Messina after a campaign through Sicily entailing great hardship and exposure. Large convoys were received from casualty clearing stations and field ambulances in forward areas; and the hospital itself functioned as a C.C.S. for half this period. In more normal circumstances, some of these cases might not have been evacuated to a base hospital. In view of the urgent need to free beds, the nonarticular cases were treated energetically from the first by means of procaine injection and manipulation, with the result that the number who could not be returned to full duty within 12 days was very small. Some cases of typical fibrositis were observed to develop pain in the distribution of the sciatic nerve, and this was considered to be a more common cause in this series of sciatica than prolapse of an intervertebral disc."

\section{(Lt.-Col. W. L. Ackerman)}

April-July, 1944.

Total medical admissions, 2,094.

Fibrositis: lumbar, 39.

" gluteal, 9.

, $\quad$ shoulder girdle, 1.

, intercostal, 7.

" miscellaneous, 8.

Gluteal plus sciatic pain, 8 .

Lumbar plus sciatic pain, 1.

Sciatica: fibrositic, 6.

disc, 2.

Arthritis: acute polyarticular, 11.

, infective polyarticular, 5 .

, serum, 1 .

osteo-arthritis, 4

," rheumatoid, 1 .

," spondylitis, ankylosing, 4.

July-September, 1944.

Total medical admissions, 2,078.

Fibrositis: lumbar, 19.

, $\quad$ gluteal, 4.

, miscellaneous, 4.

Fibrositis with sciatic pain reference, 24.

Synovitis, 5.

Polyarthritis, acute, 11.
Osteo-arthritis, 4.

Old Perthe hip, 1.

Spondylitis, ankylosing, 1 .

Postural pain, 3.

Extracts from Accompanying Report.-“"Fibrositis and mild referred sciatic pain has ousted dyspepsia, diarrhoea, and headache as the chief cause of frequent and prolonged hospitalization. Most of these patients have been in several hospitals-average two months-and by the time we see them the residual pain and intensity is difficult to estimate owing to the impaired functional background. The man at this stage is often reconciled to being a chronic case. It is suggested that more efficient results would be obtained if these "rheumatic" patients could be referred to one hospital for all investigation and treatment; and, if mild pain persisted after a certain time, a decision other than to transfer him to another hospital might be agreed upon, if necessary the medical category being lowered temporarily."

\section{No. 45 General Hospital, Malta}

(Lt.-Col. R. E. Tunbridge and Major W. A. Dewer)

July-September, 1943.

Total medical admissions, 1,488.

"Arthritis," 1.

Fibrositis and lumbago, 14.

Sciatica; 4.

Neuritis, 4.

"Rheumatism," 8

O.P. Dept., Total 308.

Osteo-arthritis, 3.

Sciatica, 5.

"Rheumatism," 4

Fibrositis and lumbago, 13.

Neuritis, 4.

\section{(Lt.-Col. J. Halliday Croom)}

October-December, 1943.

Total medical admissions, 1,117.

Acute rheumatism, 7.

Fibrositis, 23.

Infective polyarthritis, 6 .

Osteo-arthritis, 2.

Of 11 Medical Boards, 2 were on cases of rheumatic diseases.

Of 7 cases evacuated to U.K., one was for fibrositis. In addition there was one naval patient with severe sciatica.

January 1st-February 23rd, 1944.

Total medical admissions, 131. Acute rheumatism, 1.

Subacute rheumatism, 4 .

Lumbago, 3.

Synovitis (acute), 2.

O.P. Dept., Total 56.

Subacute rheumatism, 3 .

Fibrositis and lumbago, 11.

Osteo-arthritis (spine), 2.

Of 10 Medical Boards, 3 were on cases of rheumatic disease.

No cases were evacuated to U.K. for this cause.

April-June, 1944 (in Italy).

Total medical admissions, 879 (379 Yugoslavs). "Rheumatism": British, 16; Yugoslavs, 17.

\section{GibraltaR}

Precise figures were not available, but an unofficial report from Lt.-Col. L. Howells (officer-in-charge of 
medical division, Military Hospital, Gibraltar, 1941-1943) may be quoted as being his subsequent impression of the problem presented by the chronic rheumatic diseases:

"We certainly found fibromyositis a problem at Gibraltar. My recollection is that we found it a common and a difficult complaint to treat and we had to evacuate a large number of such cases. We attributed this to the humid atmosphere of the Rock, especially during the periods when the 'Levanta' enshrouded the Rock. Old 'rheumatic' subjects who had kept their symptoms in abeyance for years found that they relapsed soon after arriving in Gibraltar and that they soon improved after leaving. Chronic arthritic manifestations and acute rheumatic fever were not common. Apart from the climatic factor, I have little doubt that the mental stress consequent upon the peculiar conditions associated with service in war-time Gibraltar, and a consequent desire to get away, played some part in the relative frequency of fibromyositis. In other words, in some it was a psychosomatic manifestation."

\section{British Liberation ARMY 10 C.C.S. \\ (Major J. Ranking)}

September, 1944-April, 1945.

Total medical admissions, 3,096.

Chronic muscular rheumatism, 157.

Sciatica, 38.

Rheumatoid arthritis, 2.

Osteo-arthritis, 2.

Note by Major Ranking.- "Soldiers of good temperament appeared to recover fairly quickly under adequate treatment, but in a large number of cases downgrading to a lower medical category appeared to be the only solution."

\section{No. 101 General Hospital \\ (Lt.-Col. G. Mitchell Heggs)}

August-September, 1944.

Total medical admissions, 665. Rheumatoid arthritis, 1.

Osteo-arthritis, 1.

Non-articular fibrositis, 15.

Other types, 3.

Acute and subacute rheumatism, 2.

October-December, 1944.

Total medical admissions, 1,214.

Rheumatoid arthritis, 1.

Osteo-arthritis, 1.

Spondylitis, 4.

Unclassified, 4

Fibrositis, 44.

Prolapsed disc, 17.

Other types, 2.

Acute and subacute rheumatism, 4.

anuary-March, 1945.

Total medical admissions, 1,910 .

Rheumatoid arthritis, 8.

Osteo-arthritis, 10.

Spondylitis, 3.

Unclassified, 4

Fibrositis, 68.

Sciatica, 9.

Prolapsed disc, 6.

Other types, 2.

Acute and subacute rheumatism, 8.
April-June, 1945.

Total medical admissions, 1,846

Infective and rheumatoid arthritis, 22.

Osteo-arthritis, 8.

Fibrositis, 68.

Sciatica (disc), 31.

Acute and subacute rheumatism, 17.

Note by Lt.-Col. Mitchell Heggs: "Fibrositis became a very common complaint in the autumn in Normandy, and increased throughout the winter of 1944-45. The incidence of sciatica seemed to me to be particularly large in this theatre as compared to Middle East and Italy, although I have no figures to prove this."

\section{No. 8 General Hospital \\ (Lt.-Col. J. Osborne)}

The consolidated figures for three quarters were available. Of 10,144 medical cases admitted, 484 were on account of chronic rheumatic diseases and were divided as follows:

Muscular rheumatism, 265.

Sciatica, 118.

Infective arthritis, 60.

Osteo-arthritis, 34

Spondylitis, 7.

\section{P.A.I. FORCE}

(Persia and Iraq Force-later P.A.I. Command)

In the consulting physician's report for JanuaryJune, 1944 (Brig. F. M. Lipscomb), there is a paragraph under the heading of fibrositis: "The group consisting of fibrositis, myalgia, and allied conditions is remarkably small, with an incidence of only $1.7 \%$ of all hospital admissions for the half year. These figures are in marked contrast to those seen in the United Kingdom and are interesting in view of the extreme climatic changes in this Command, where cases of frostbite and heat stroke may both be seen during the same half year, and a daily temperature swing of over $40^{\circ} \mathrm{F}$. is not uncommon. The rainfall, however, is, as a whole, low."

In the subsequent report for July-December, 1944 (Brig. T. C. Hunt), the admission rate for this group is given as 0.5 per 1,000 per month. He comments on the number of cases of neuritis which had been seen in this half year. These cases were characterized by an acute onset with severe pain, followed in 2-3 weeks by weakness and wasting, usually in the shoulders. Sensory loss was variable, but generally slight, and it was the supra-scapular and serratus muscles which were most generally involved. Indian troops appeared to be more frequently affected than European troops. $\mathrm{He}$ is undecided as to the aetiology of these cases, which were similar to many others reported from Middle East from 1940 onwards, but inclines to an infective (? virus) origin, although the rapid response of certain cases to thiamine suggested the possibility of a dietetic or vitamin deficiency. He pointed out with regard to the fibrositic group of cases that these had increased in the late summer and autumn and were reported equally amongst Indian troops.

This Command was not popular as a place of residence amongst the troops, and the question of a psychosomatic basis for some of these cases became of importance. Indeed, Major St. John Brooks, at 
the Lahore Conference in May, 1944, speaking on neurosis in Iraq, stated that all psychosomatic complaints increased rapidly after the first year of residence in the country, and instanced "fibrositis" and " sciatica" as examples amongst British soldiers. Lt.-Col. Bhalla, speaking of Indian " other ranks," mentioned the common occurrence amongst them of "such manifestations of hysteria as backache or sciatica, the part affected being usually the one which will make the individual unfit for his job if he is dissatisfied with it."

The only analysed record from a general hospital concerning this group is for the quarter, JanuaryJune, 1943:

\section{No. 33 General Hospital, Mussaiyib}

(Lt.-Col. W. S. C. Copeman)

January-June, 1943.

Total medical admissions, 781.

Fibrositis, 36.

Osteo-arthritis, 3.

Spondylitis, ankylosing, 2

Rheumatoid and infective arthritis, 3.

A note appended to these figures records the observation that many of these cases of fibrositis appeared to have had their origin in acute illnesses of various sorts. Their average stay in hospital was 25 days with active treatment.

\section{East African Command}

Chronic rheumatic diseases were not common in this Command, although the consulting physician (Brig. E. Cullinan) stated that a large number of the native troops suffered with pains of unknown aetiology (often thought-with no evidence-to be due to a yaws infection) for which they were, however, seldom admitted to hospital. The following figures of admissions in chronic rheumatic group are from his official reports.

Rates of admission per 1,000 total strength:

Bones, Joints, Fascial, ETC.

\begin{tabular}{|c|c|c|c|}
\hline 1944 & Europeans & $\begin{array}{c}\text { Non- } \\
\text { Europeans }\end{array}$ & $\begin{array}{c}\text { All } \\
\text { races }\end{array}$ \\
\hline $\begin{array}{l}\text { January-April } \\
\text { May-July } \ldots\end{array} \begin{array}{l}\text {. } \\
\text { July-September } \\
\text { September-December }\end{array}$ & $\begin{array}{l}3 \cdot 12 \\
2 \cdot 81 \\
2 \cdot 44 \\
3 \cdot 50\end{array}$ & $\begin{array}{l}2 \cdot 0 \\
1 \cdot 64 \\
1 \cdot 39 \\
1 \cdot 31\end{array}$ & $\begin{array}{l}2 \cdot 12 \\
1 \cdot 76 \\
1 \cdot 49 \\
1 \cdot 54\end{array}$ \\
\hline
\end{tabular}

He records a syndrome which was commonly observed amongst African troops. Onset was with high fever lasting for only a few days. It was associated with pain in one or both sides of the neck and remarkable rigidity of the posterior cervical muscles, which were extremely tender. Occasionally there were some enlarged glands in the posterior triangle of the neck; but there was no evidence of superficial thrombosis. This syndrome often gave rise to chronic cervical pain for many months. Troops boarded to category B or C, diseases of the bones and joints, represented $13.3 \%$ in Europeans and $2.5 \%$ in African natives.
INDIA AND S.E.A.C.

The chronic rheumatic diseases were not much trouble in these commands according to the Consulting Physician, Brig. H. L. Marriott. He wrote (personal communication): " Perhaps I should put the position more accurately if I said that the main tropical diseases-malaria, dysentery, sprue, etc.bulked so largely that all other problems seemed small by comparison." The figures from the two annual reports of the Standing Medical Review Board at Poona, issued by Brig. J. D. S. Cameron, confirm this on the whole, although, since the figures refer only to cases evacuated back to the United Kingdom out of India from these two Commands, it would seem that the reservoir from which they were drawn may have contained a considerable total number of cases suffering from this group of diseases. It is interesting to find that Brig. Cameron specifically mentions that dysenteric arthritis was no problem in this war: "Its very low incidence was one of the rather unexpected findings of tropical disease in the India Command, contrary to what the book said."

The figures referred to above have been extracted from his reports for the years 1944 and 1945 and are as follows:

\section{Standing Medical Review Board}

1944.-Total cases, 3,261.

Fibrositis and bursitis $\ldots \quad \ldots \quad \ldots \quad \ldots \quad 10$

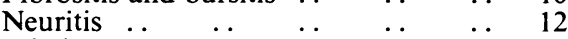

$\begin{array}{lllllll}\text { Sciatica } & \ldots & \ldots & \ldots & \ldots & \ldots & 9\end{array}$

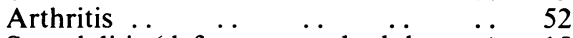

Spondylitis (deformans and adolescent) 15

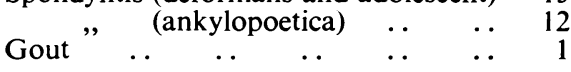

$\begin{array}{lllll}\text { Total } & \ldots & \ldots & \ldots & 120\end{array}$

The total number of rejections during this year on account of chronic " rheumatic" complaints was 29 out of a total of 262 .

1945.-Total cases, 8,812.

Fibrositis and bursitis .. $\quad \ldots \quad \ldots \quad \ldots 20$

$\begin{array}{llllll}\text { Polyneuritis } & \ldots & \ldots & \ldots & \ldots & 9\end{array}$

$\begin{array}{llllll}\text { Neuritis } \ldots & \ldots & \ldots & \ldots & \ldots & 19\end{array}$

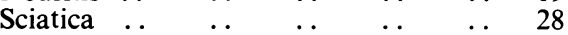

$\begin{array}{llllll}\text { Rheumatism } & \ldots & \ldots & \ldots & \ldots & 9\end{array}$

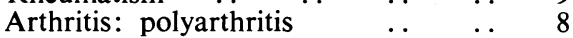

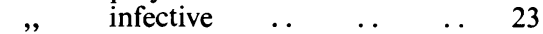

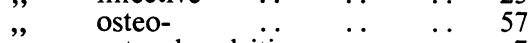

$\begin{array}{llll}\text { ", osteochondritis } & \ldots & \ldots & 7\end{array}$

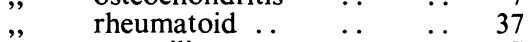

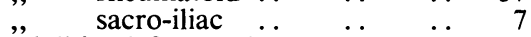

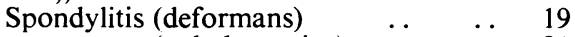

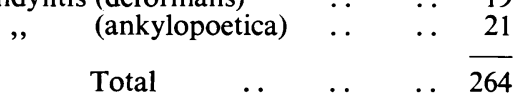

My thanks for permission to publish this section of the "Medical History of the War" are due to Major-General Sir A. G. Biggam, Sir Arthur MacNalty, and Dr. Charles Newman.

\section{REFERENCES}

Copeman, W. S. C. (1940). J. R.A.M.C., 74, 277.

(1943). Brit. med. J., 2, 263.

and Ackerman, W. L. (1944). Quart. J. Med., 13, 37.

, and Pugh, L. G. C. (1945). Lancet, 2, 553

Elliot, F. A., and Kremer, M. (1945). Ibid., 1, 4.

Mylechreest, W. H. (1945). Annals of the Rheumatic Diseases, 4, 77

Pugh, L. G. C., and Christie, T. A. (1945). Ibid., 5, 8.

Stott, A. W., and Copeman, W. S. C. (1940). Lancet, 1, 1116. 